\title{
ARTHUR BLISS SEYMOUR
}

\author{
$1850 \sim 1933$
}

篮彗翰炏

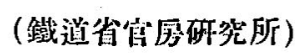

いやしくも菌類の學問にたづさはるほどの人で，Host Index of the Fungi of North America の著者 Arthur Bliss SeYMoUR の名を知ら好ものとてはあるまい。同印 1933 年 3 月 29 日病攻。其の傅記が吓年の Mycologia 第 4 號に出てるる。其の筆者 I. R.

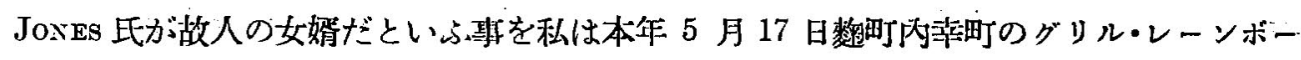
で宫部先生から敎はつて, 道理で委細を悉してあるわいと思つたのである。

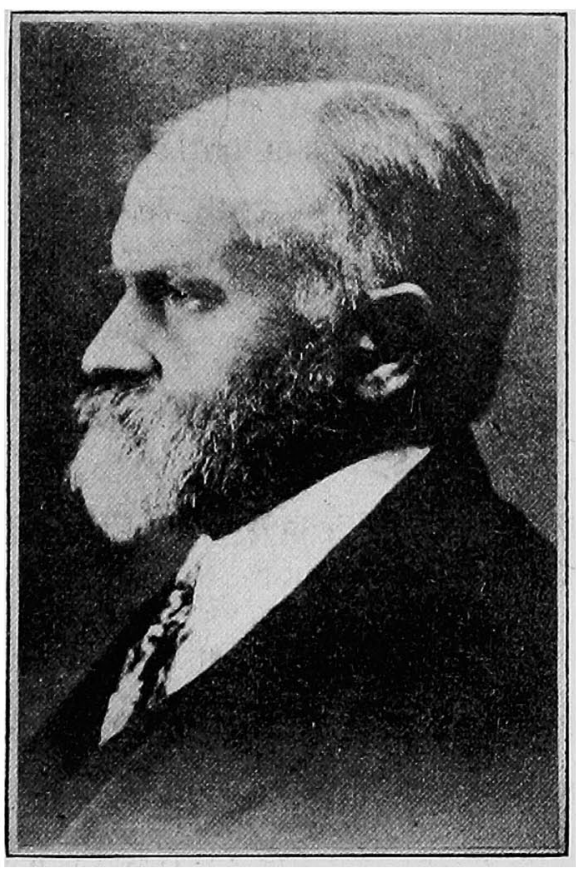

故 Arthur Bliss Seymour (Mycologia より)

シーモア逝去の日は米國菌學の開拓者 de SCHWEINITZ の㱛後, 满一世紀に只の 1、年不. 足する日であつたといふ。誠に此の學問の建 設時代の後牛期に橋を架したものは S 氏であ つた。彼れの系譜上，米國での第 1 代は Richard SEYMoU: とて英國から 1639 年に 移住，カネクチカット州 Hartford 一居をト した。爾後 6 代の間或は同州に又はマサチウ 七ッッ州に住局。父の代になつて 1835 年に 他の開拓者と一所にイリノイ州 Moline に移 つたが，父は其處に出來た教會の牧師さんだ つた。母藩英間苗族の出で，名を Mary Burss。其の丽親加徳導者として 1837 年に布 姓に赴任した關係から母は同島の生れになつ てるる。斯くてシーモアにはピューリタンの 血が流れてるるのである。

幼時天資明敏。5つになるまでの何時だかに猖猴熱に罹つたが雼め生れるつか始部分 的の楒になつた。此の故に乘所はにかみやで，內觀的傾向を帶びるに至つた。自然科學 へのインステンクトはいつかは此の少年を其の身邊の植物への親しみに導いたのであつ 
て、イリノイ州の高原がずつとミスシッピー川畔ハとなだ扎行く所，雅多な草花に彩どら

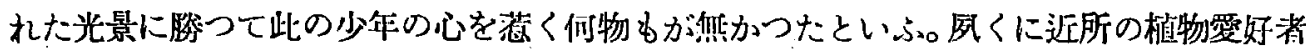
の权父さんたちから普通の植物の名稚を查定する方法を敦へて貲つたが，此事が彼れるし て普通學課以外に補習科でラテン語を學がやうにしたのであり，且つ又此の趣味が其の入 學すべき學校の選睪上大なる支配力を有したのだある。即ち近くの Knox 大學に入學才 べきを却つて，BUnnuL 肴授が居るからとてイリノイ大學へ這入つたのである。入學の

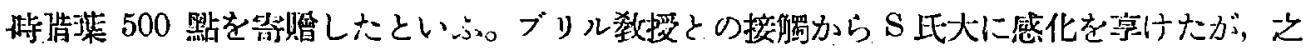

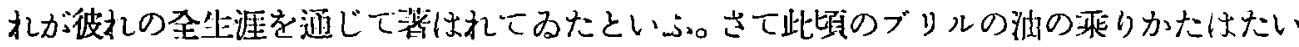

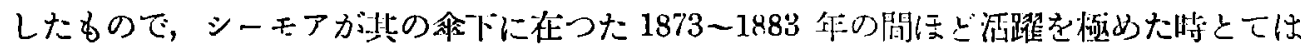

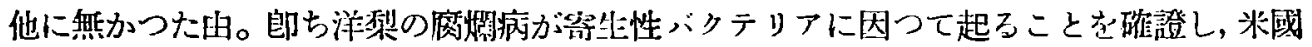

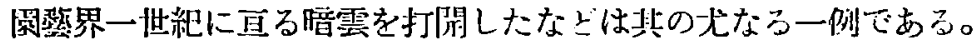

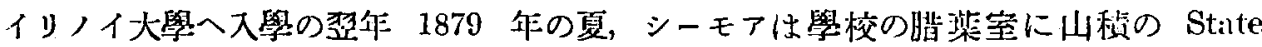
Survey Collections の整理を托されしたが，翌 1880 年夏には自ら採集旅行に出揶け大に 客生菌類への與味を㬇起してるるところへF.S.EAHLE と交際するやうになつたが，之れい

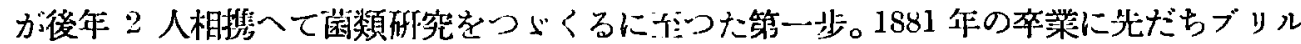

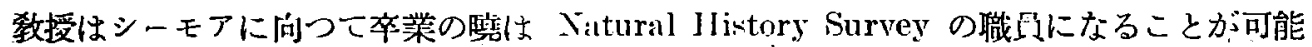

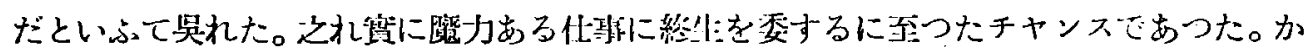
くて此の職に就いたのだが彼机自ら誌してのく：- “約 2 年間といふむの私はルーべを乎

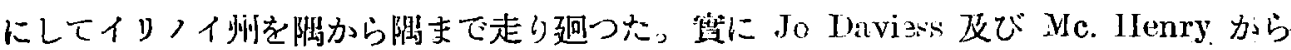

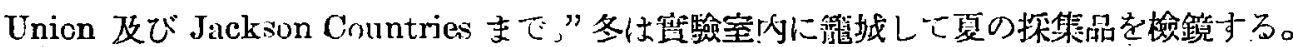

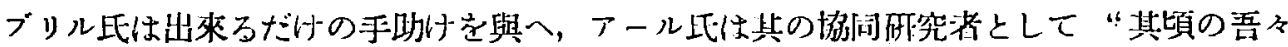

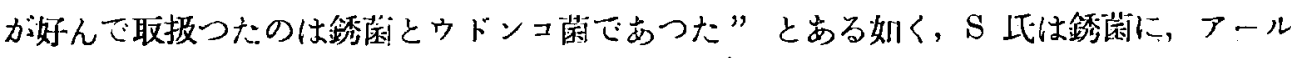

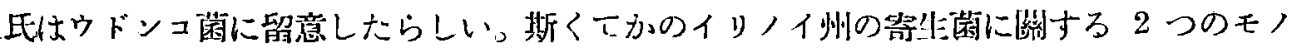

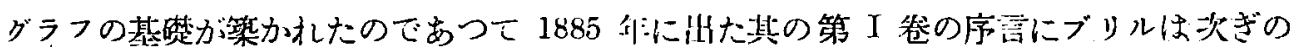
如、畫いてみる:-

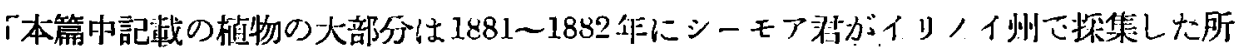
のものであつて，標本の總點數は通じて 3784 點, 其以化重複せるもの及び又同一種

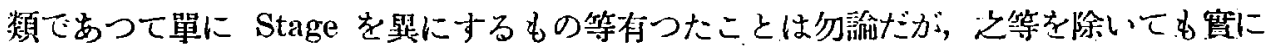

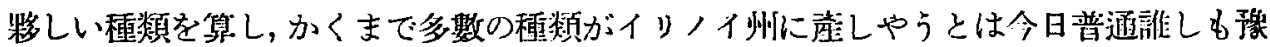
想しなかつた所である」

か১りける程にシーモア早やくも Index の必姴を感じて 1881 1883 年の，2 冬の間 曹ら菌類に關する荣引の編算に從事したのであつた。1483 年の泰“预机てから指導に预 りたいと希つて拁つた Prof. W. G. FARLOW から臨時の仕事ではあるが期乎として暫く

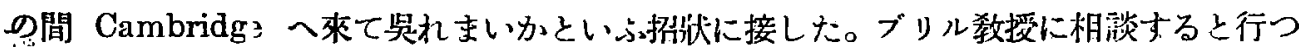




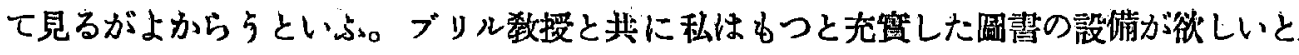

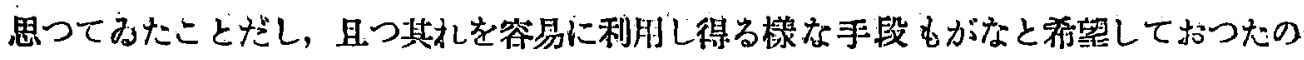
である。Cambridge にした所で同じ程䁃の小さな Index を有し居るに過ぎないので大

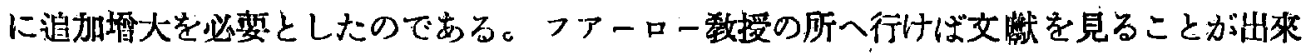

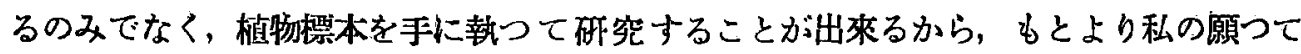
るない仕合せとする所である”といら事になつた。而して更に日はく：-

“イリノイに於ける吾等の日標は其の州だけの菌頪にいぶあつたが，フアーロー㸚 授の抱負は全北米合臬國の菌類の一大目錄を編述せしとするに在つた。”

からいか毣合で其の次の作は Harvard Mycological Index を作る仕事に㳸頭して幸 福に打過ぎたのであつて，惯に彼礼が Indexに彼れの生涯を揍ぐるに至つた籍一階段を゙ 為したのであつた。

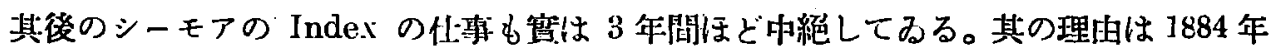

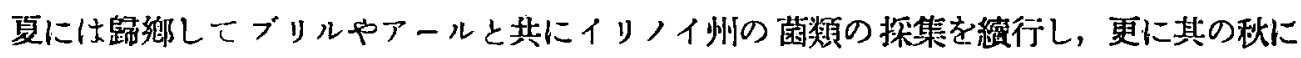
は North-Pacific 鐵道を打跨いでュロンビア川沿岸まで探集旅行を試みたのであつた。 而して丁度其疑 Illinois State Laboratory 所長 Forses 氏からシーモアへ，來年の夏

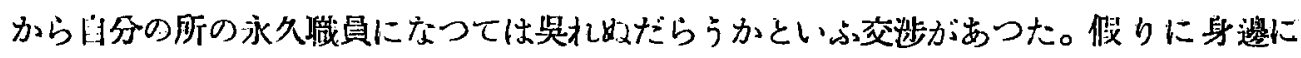

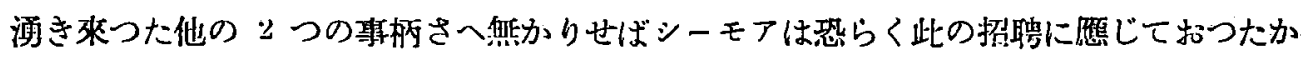
も细礼ない2 つの事柄の第一は 1884 年 12 月际びフアーロー敉授から手紙があつて自 分は今度 Dr. GraY に阹行して Pacific Coast への冬期逘征に加はりたいので其不在中

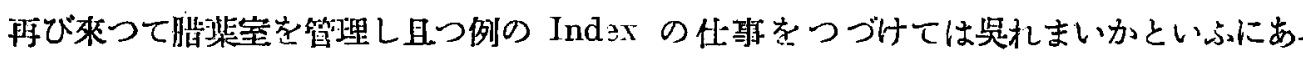

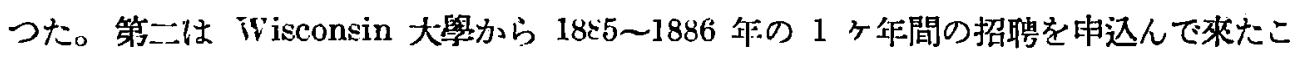
とであつた。一此此のウイスコンシンには Prof. W. TRelease が展つたのであつて, 同 氏はむとフアーローの䎑下゙でシーモアの前任者として闹じ Harvard Index の性事をや つてみたことがあるのである。然るに同氏は 1885 年にセントルイに博任しワシントン 大學とミッ゙リー概物圆とに策務寸ることになつたのである。此の意外なる契機が透にシー モアをして，TrELEASE 去り，後 BARNEx 㸚授來るまでの椤ぎにウイスコンジン大學で

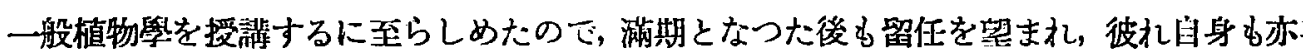

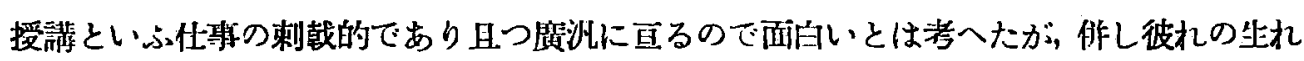

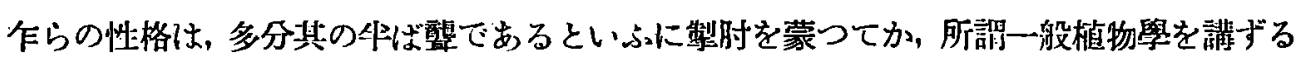

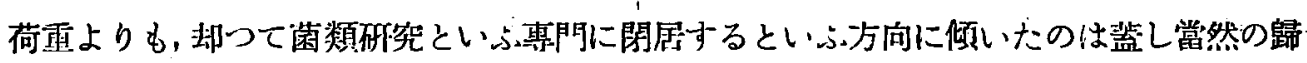
趣であつた。

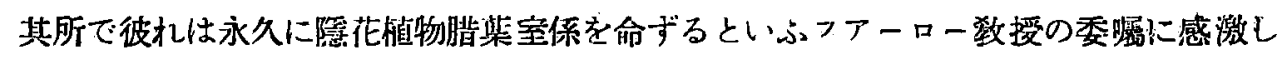

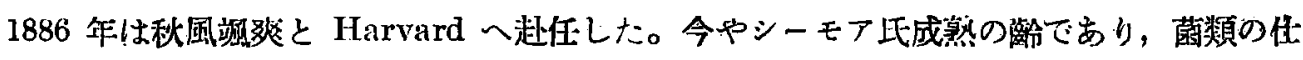
事も手に入つたもの，向後の彼机の生涯を支畞するむのとては獨り Harvard Index. 
るのみといらことになつた。此の Index に關する㤌乘は前記の如く 1883 年に指を染

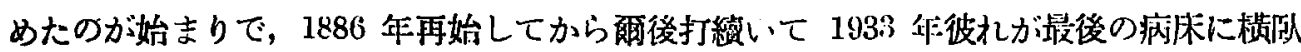
ナるまでに及んでるる。批判的植物學の Indexing に於て，これ标ど長年月に亘つた倜

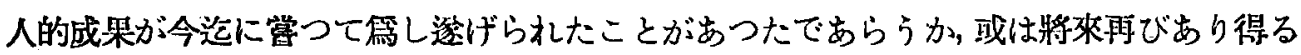
であららか。

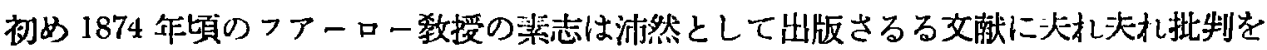
加へて Indexに訛製し自己の手控にして置く位の輕い考へであつたらしく，或は其れしを 徨めて後日モノグラフか何か作るかむ知犼といふ位の考へであつたらしい。篮し同敎 授の斯うした装志は Prof. GRAY や de BanX に師事した頃より早やくも芽生へて居つ たらしい。此の兩光翟は各的其の尃閆とする分野に於ける秀でたる Monographer であ

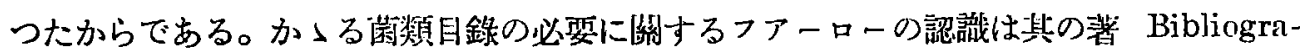
phical Index の序に於て此程のそノグラフが 1822 年及 1834 年に de ScerweINITz に

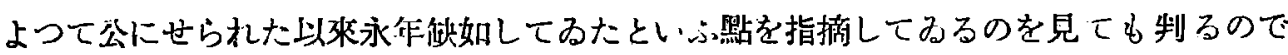
ある。

同じ樣な考へは，素より多くの他の人々にむ抱かれたところであつたが，作しこれまで

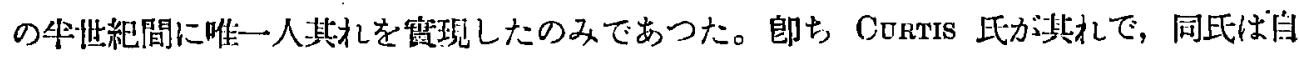
己所有の腊禁をもとっして Index を作つたのである。

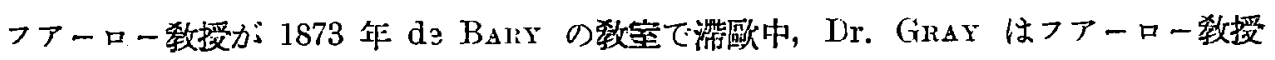
の篇めに上記カーチス氏の谐禁全部を買ひ取つて與孔た。こ扎が今日の FARLOW Her-

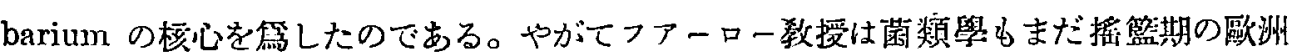

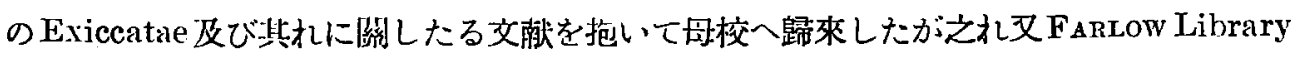
の礎を築いたのであつた。同数授はモノグラフ的旰究材料を蒐集すると共に此等栁糊の 檢闞に便せんとて Inder を必耍としたのである。

1886 年以降シーモナ氏は永久に整ら Index 作整の代翡に沒頭したのであつたがフ アーロー数授は幸に絶へず Harbarium 及び Library の內容を豐かにすることに倾注 したのでシーモアの感湤はいよいよ加はつて行くばかりであつた。加ふるにフアーロー

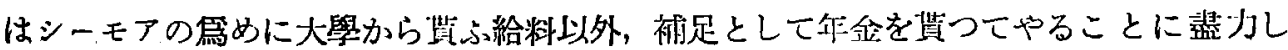

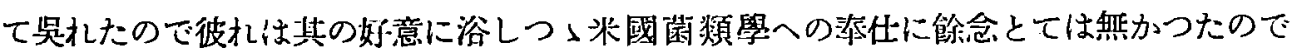

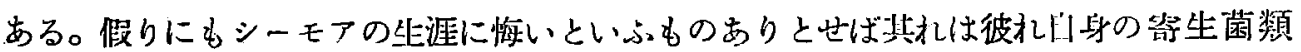
の研究をやりたく思つたであらう處の日のを全然放抛せねばならなかつたといら點であ

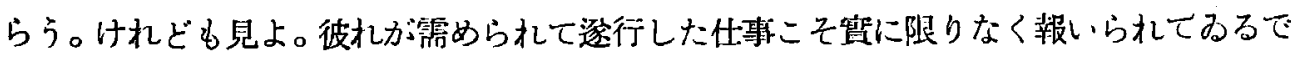
はないか。

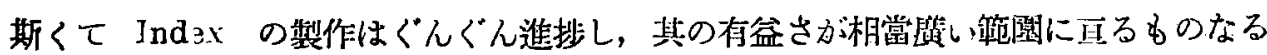

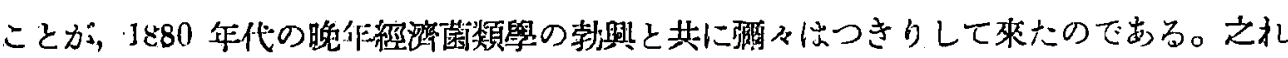


に呼應してファーロー敎授は Harvard Jibrary Series の刊行に着手したのであつだ 刊行の第一は FarLow-Trelease 著 Iist of Works on North American Fungi, 1887 と其のサプレメシト，此の网者が價偡に葍んだものであつたと共に，更らに其の次ぎに

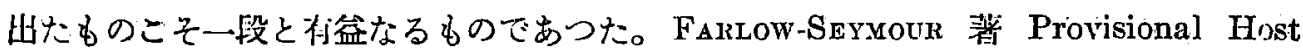
Ind9x of the Fungi of the U.S. Part I, 1:88, 其の Part II, 1890 及び其の Part III; 1891 が其れしであつた。惟ふに此の 3 册の出版物に䅎つて覓に時を得て刊行され，且つ庶

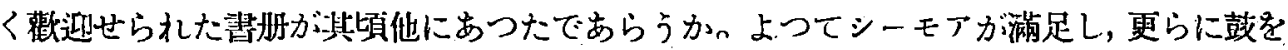
鳴らして梦て立つたことはいふまでもなかつた。农之等の書册の出現は重なて後に生れ 出るもの〉更らに大なるものであることを姚言したとも云ひ得る。

元來 Harvard Indэx๖ なるものは相關する Author Index, Host Index'及び Species Index の 3 つから成立してみる。就中出版上此輘的精確に行はれ易く绑命に薑 ばら奴のは Author Indəx であつて Most Index 之狄に留ぐ。 Spacies Index は未だ

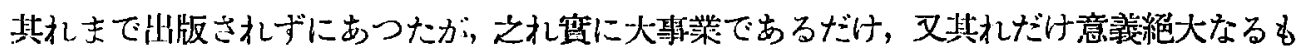
のである。此の Species Index への徰の關心が段々高まつて來たので逐に CARNEGIE Institution が版を引受けやうといふ邪となり，其の䋺果 1905 年になつてやつと FaxLow 藷 Bibliographical Index of North American Fungi 第 I 参, 第 1 册だけが 出た。此の 1 那にはAbsothallus から Badhəmia までのあらゆる Species が包含され

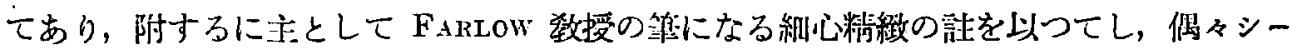
モアのサインの入つた䛉も散見する。該册に見ゆるフフーローの序言によると此の

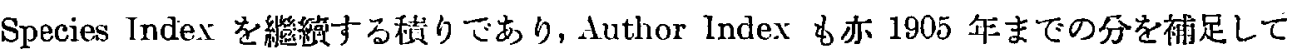

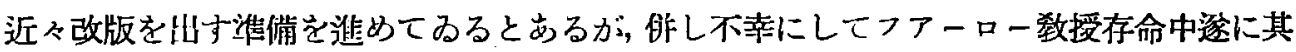

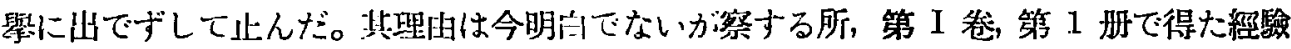

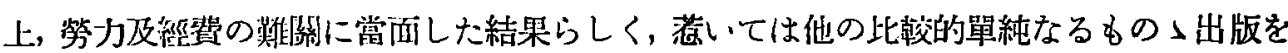
む因難に陷らしぬたらしい。们となれじ 1905 年に出た前記の笏 1 册の序にあるところ のフアーロー敎授の計算によると 1903 年までの交献の總數は大體 150,000 を算し，第

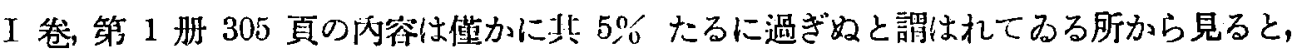
箬し全部を版するとせば 5,000 頁を必要とすることょなり，册數で云へば第 1 册と同 型のもの 18 册を必姦とすると訊は机てるるからである。

さてシーモアも段々に年等る。Indexに作るべき材料の分量は加はるばかりであり，複

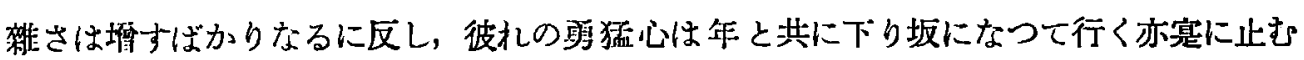
を得ない。

さり乍ら率に彼れの啳生生 20 年間の勞苦の一部分は稍酬ひらるらに至つた。郎ち彼れ が永い永い間忍從の內に希知しおつた SExмour 著 Host Index of the Fungi of North America が 1929 年になつて Harvard University Press から出版されたことである。 


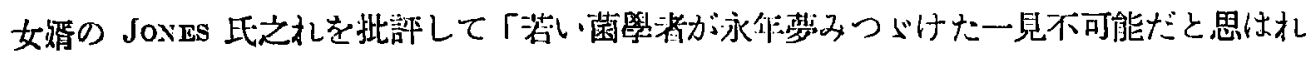
た希望は遂に娃に空現となつて來た」と述べてるる。㬈し前後 40 年の長年月に百るシー

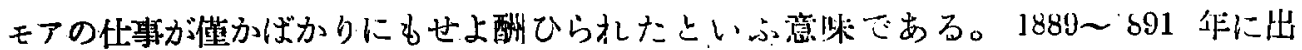

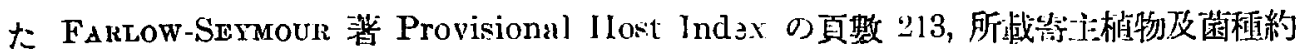
23,000であるに過きざるに比し，倬と此の 1929 年の代版物は Double-Column の 717

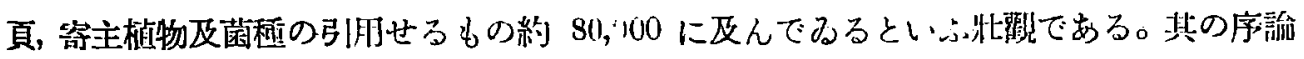

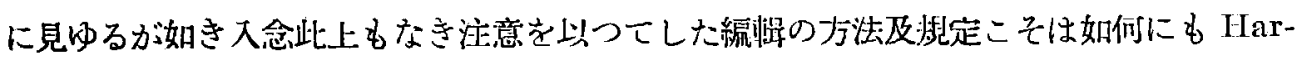

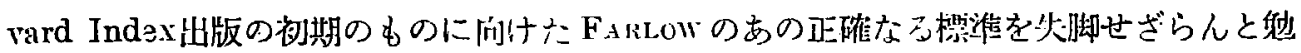
めたS氏の努力の程を想はしむるもがのある。げにやシーモア坁は此の一都をWilliam

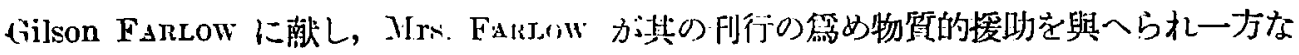
ら好御忙話になつたと感謝してみる。 